\title{
Tujuan Hidup-Prioritas dan Otoritas: Dimana Kita Memilih?
}

\author{
Rabiudin ${ }^{1}$ \\ Institut Agama Islam Negeri Sorong \\ rabiudin27@gmail.com
}

\begin{abstract}
Abstrak
Kadang kita tidak menyadari bahwa kita memiliki otoritas atas diri kita sehingga kita bebas mengatur prioritas Kita, oleh karenah ketidak sadaran membuat kita berada dibawah kendali orang lain sehingga tidak mampu lagi mengatur diri sendiri.

Keyword: Prioritas, Otoritas, Kendali
\end{abstract}

\section{Pendahuluan}

Setelah terlalu banyak teori yang menjelaskan tentang kehidupan hingga kematin, hingga akhirnya orang sibuk untuk unggul sendiri dan menyingkirkan orang lain. maka sampailah saatnya kita beranjak ke topik lain yang sedikti mencerahkan. Sedikitnya kita bisa memiliki prioritas hidup dengan prioritas hidup atau prioritas mati. kali ini saya akan membahas tentang satu kata yang mungkin banyak orang sering memperdebatkan bahkan terjebak dalam pilihan kata itu kata itu adalah prioritas dalam kehidupan manusia itu punya prioritas tentunya bahkan kalau misalnya kita sakit mata kita bisa menilai bahwa yang tidak punya prioritas dalam hidup ini maka ia adalah orang-orang yang akan ketinggalan bahwa dalam hidup kita dalam setiap menit dan detiknya kita dihadapkan dengan sebuah pilihan ada sebuah pepatah mengatakan bahwa saat anda berada di pagi hari maka ada dua pilihan yang akan dihadapkan pada anda yang pertama adalah bangkit bangun dari tidur Kemudian menjalankan aktivitas sehari-hari Kemudian yang kedua adalah melanjutkan tidur anak kembar tergantung mana prioritas Anda ini adalah kiasan tentang bagaimana prioritas itu terbentuk dalam diri kita karena seperti yang disebutkan sebelumnya bahwa dalam setiap detik pikiran kita dihadapkan dengan sebuah pilihan dan pilihan itu tentunya 
bukan datang dengan sendirinya akan tetapi kadang sengaja kita hadirkan dalam hidup kita misalnya kita diterima untuk bekerja dalam sebuah perusahaan atau sebuah kantor kemudian disana kita akan dihadapkan dengan pilihan lain lain lagi seperti halnya kita dituntut untuk bekerja ekstra bekerja lebih keras maka prioritas kita selanjutnya adalah Misalnya agama habis itu kesehatan habis itu kenyamanan habis itu gaji misalnya kita bekerja dalam perusahaan tersebut saking kerasnya bekerja sehingga misalnya kita tidak diizinkan untuk melaksanakan ibadah dalam waktu ibadah Tertentu bisa maka kita tinggal memilih apakah ibadah agama adalah prioritas atau tidak kalau seandainya ia adalah prioritas maka kita akan melepaskan semua pekerjaan itu karena satu prioritas penting yang telah kita yakini.

\section{Metode}

Metode yang digunakan adalah metode deskripsi yang menguraiakan strategy sukses satu persatu melalui mengkajian deskriptif dan terarah pada satu kajian utama tentang pola pengaturan hidup.

\section{Pembahasan}

Kesadaran kita atas pikiran kita sendiri adalah kesadaran akan isinya: apa yang kita pikirkan. Mode kesadaran ini membuat seseorang berwibawa tentang apa yang dipikirkannya. Bahkan anak-anak (yang belum tahu apa yang mereka pikirkan) adalah otoritas (ini disebut otoritas 'tanpa disadari') atas apa yang mereka pikirkan. Namun, otoritas ini tidak seluas ke fakta bahwa seseorang berpikir. Kesadaran (ini disebut 'kenalan') dengan apa yang dipikirkan seseorang sebagai kesadaran akan sebuah proposisi, dan sebuah proposisi (bahkan proposisi yang Anda pikirkan), tidak seperti fakta, bukanlah alasan untuk mempercayai apa pun (tentu saja bukan alasan untuk percaya Anda berpikir).

Mengidentifikasi tujuan adalah keterampilan penting untuk kesuksesan pribadi dan bisnis. Sementara hal-hal seperti Resolusi Tahun Baru sering kali tidak berhasil (60\% orang mengabaikan Resolusi Tahun Baru mereka dalam waktu enam bulan), 
mengidentifikasi tujuan spesifik yang dapat ditindaklanjuti dapat membawa Anda jauh.

Sebuah studi oleh profesor psikologi Dr. Gail Matthews di Universitas Dominika menemukan bahwa orang yang menuliskan tujuan mereka berhasil mencapainya 50\% lebih sering daripada mereka yang tidak. Peserta penelitian dari segala usia, mewakili berbagai macam profesi, dan berasal dari Amerika Serikat, Belgia, Inggris, India, Australia, dan Jepang. Langkah-langkah tambahan yang membantu peserta mencapai tujuan mereka termasuk mengidentifikasi langkah-langkah yang dapat ditindaklanjuti untuk mencapai tujuan mereka, berbagi tujuan mereka dengan orang lain, dan melaporkan setiap minggu kepada orang tersebut tentang kemajuan yang dicapai menuju tujuan mereka. Kemampuan untuk mengasah langkah-langkah apa yang paling penting untuk mencapai tujuan Anda sangat penting. Tapi bagaimana Anda bisa tahu tugas mana yang harus difokuskan? Apakah ada cara untuk mengidentifikasi pekerjaan dan tugas mana yang paling penting?

\section{Ubah Pola Pikir Anda}

Menetapkan prioritas dan tujuan, jenis yang memajukan karir Anda, membutuhkan perubahan pola pikir. Sebagian besar dari kita cenderung menempatkan prioritas yang lebih besar pada hari ini dan apa yang terjadi saat ini. Jika kita benar-benar mengambil pandangan jangka panjang, kita akan lebih banyak berolahraga, makan lebih sedikit junk food, dan berhenti menunda-nunda, kan.

Bagaimana Anda mengubah pola pikir Anda?, Anda perlu membayangkan hidup Anda satu tahun, tiga tahun, lima tahun dari sekarang. Apa yang ingin Anda capai?. Siapa dan di mana Anda ingin menjadi?

Tapi jangan hanya membayangkannya, bayangkan bagaimana rasanya mencapai tujuan Anda dan kemudian tuliskan! Menuliskan tujuan Anda akan memaksa Anda menjadi sangat spesifik, membantu Anda memahami tindakan apa yang perlu Anda ambil, dan menyediakan kerangka pengambilan keputusan yang dengannya Anda 
dapat mengevaluasi tindakan dan peluang lain dalam hidup Anda. Apakah ada sesuatu yang membuat Anda lebih dekat atau lebih jauh dari tujuan Anda? Jika Anda memilikinya secara tertulis, maka Anda selalu dapat kembali dan melihat saat Anda memutuskan di mana menginvestasikan waktu dan energi Anda. Tujuan dan prioritas tertulis juga memungkinkan Anda melihat (dan merayakan!) kemajuan Anda.

Berikut ini adalah sistem dua langkah umum untuk menetapkan prioritas. Pertama, Anda harus mengidentifikasi tujuan Anda. Kemudian Anda akan ingin mengatur daftar tugas Anda dengan berfokus pada tugas-tugas yang paling "menghasilkan uang". Mari selami setiap langkah ini secara lebih rinci.

\section{Identifikasi Tujuan Anda}

Anda tidak dapat memprioritaskan daftar tugas dengan benar sampai Anda mengidentifikasi apa yang sebenarnya ingin Anda capai dalam skala besar. Mulailah dengan mengambil pandangan sekilas tentang hidup Anda dan perlahan-lahan tentukan tujuan yang lebih spesifik. Misalnya, Kim baru saja mendapat pekerjaan mengantongi bahan makanan di supermarket lokal. Dia sangat senang membantu pelanggan dan memutuskan dia ingin menjadi manajer toko dalam lima tahun. Itu tujuan besarnya. Sekarang dia perlu lebih terperinci dan mengidentifikasi tujuan spesifik di sepanjang jalan. Agar Kim menjadi manajer toko, dia harus terlebih dahulu lulus dari tugas mengantongi bahan makanan ke posisi kasir, kemudian menjadi asisten manajer, dan akhirnya memenuhi syarat untuk status manajer toko.

Kim juga tahu bahwa mencapai tujuannya akan membutuhkan lebih dari sekadar muncul setiap hari. Dia memutuskan untuk mendaftar di kelas malam di community college setempat untuk meningkatkan pengetahuan bisnis dan keterampilan manajemen orangnya.

Masing-masing tujuan ini - mencapai posisi kasir, menerima sertifikat bisnisnya, dll. — adalah batu loncatan yang membawanya ke misi menyeluruhnya: menjadi manajer 
toko. Anda dapat mengambil pendekatan yang sama. Setelah Anda menemukan tujuan besar Anda, identifikasi tujuan yang lebih kecil di sepanjang jalan.

\section{Tetapkan sasaran S.M.A.R.T.}

Saat kita membahas topik tujuan, setiap tujuan yang Anda tetapkan harus S.M.A.R.T. Spesifik, Terukur, Dapat Dicapai, Relevan, dan Tepat Waktu.

Spesifik: Semakin spesifik tujuan Anda, semakin besar peluang Anda untuk mencapainya. Misalnya, daripada mengatakan Anda ingin tinggal di pantai, katakan, "Saya ingin tinggal di rumah dengan empat kamar tidur, tiga kamar mandi di pantai di Monterey, California."

Measurable: Tujuan Anda harus terukur. Dapatkah Anda mengidentifikasi tonggak pencapaian untuk mencapai kesuksesan? Jika tidak, akan sulit untuk menentukan apakah Anda berada di jalur yang benar atau tidak.

Attainable: Apakah tujuan Anda benar-benar dapat dicapai untuk Anda? Tidak hanya secara luas, "apakah mungkin?" cara, tetapi, "Apakah saya bersedia membuat pengorbanan yang diperlukan untuk mencapai tujuan ini?" Jika jawabannya tidak, maka tujuan Anda perlu didefinisikan ulang.

Relevan: Tujuan yang relevan adalah tujuan yang Anda pedulikan. Tanyakan pada diri sendiri apa yang sebenarnya Anda inginkan. Hanya karena orang lain menginginkan hal-hal tertentu tidak berarti Anda juga harus demikian. Lakukan pencarian jiwa. Jika Anda benar-benar bersedia untuk bekerja keras yang diperlukan untuk mencapai suatu tujuan, itu lulus uji relevansi.

Tepat waktu: Tujuan tanpa rencana dan kerangka waktu pasti tidak akan pernah tercapai. Sangat mudah untuk bermimpi tentang masa depan, tetapi Anda tidak akan pernah sampai di sana jika Anda tidak mengambil tindakan. Pastikan setiap 
tujuan yang Anda tetapkan terikat waktu. Jika Anda tertinggal dalam timeline Anda, Anda selalu dapat menyesuaikan.

\section{Atur Tugas Anda}

Sekarang setelah Anda memahami apa tujuan Anda dan langkah-langkah yang perlu Anda ambil untuk mencapainya, Anda dapat mulai merencanakan tugas harian untuk membantu Anda mencapainya. Tugas-tugas ini kemudian dapat diatur dalam daftar tugas Anda. Kembali ke contoh kita sebelumnya, Kim tahu bahwa dia harus terlebih dahulu mengamankan posisi kasir sebelum dia bisa menjadi manajer toko. Bagaimana dia bisa mengoptimalkan pendekatan dan kinerjanya untuk mencapai ini?

Kim memutuskan untuk datang 10 menit lebih awal untuk bekerja setiap hari, menyelesaikan setiap tugas yang diberikan tanpa mengeluh, dan membantu manajer toko saat ini jika memungkinkan. Dia menganggap kerja keras dan inisiatifnya yang konsisten akan memungkinkannya untuk dengan cepat menaiki tangga perusahaan.

\section{Metodologi yang Terbukti untuk Menetapkan Prioritas}

Kami baru saja menguraikan pendekatan dasar untuk menetapkan prioritas: identifikasi tujuan Anda, lalu atur daftar tugas harian Anda berdasarkan kepentingannya. Ini adalah sistem yang sederhana dan sangat dapat ditindaklanjuti. Tetapi mengetahui tugas mana yang harus diprioritaskan tidak selalu mudah(Rabiudin, Taruh, \& Mursalin, 2018). Untungnya, ada beberapa kerangka kerja yang dapat Anda gunakan untuk membuat Anda tetap fokus pada hal yang benar. Kami akan menjelajahi beberapa di antaranya sekarang.

\section{Gunakan Kotak Eisenhower}

Kerangka kerja yang populer dan sangat efektif untuk menetapkan prioritas dikenal sebagai Kotak Eisenhower. Dinamakan setelah Presiden AS Dwight D. Eisenhower 
karena tingkat produktivitasnya yang luar biasa, matriks ini mengklasifikasikan tugas ke dalam salah satu dari empat kotak: Penting dan Mendesak, Penting tetapi Tidak Mendesak, Mendesak tetapi Tidak Penting, dan Tidak Penting atau Mendesak.

Gambar ini menggambarkan prinsip:

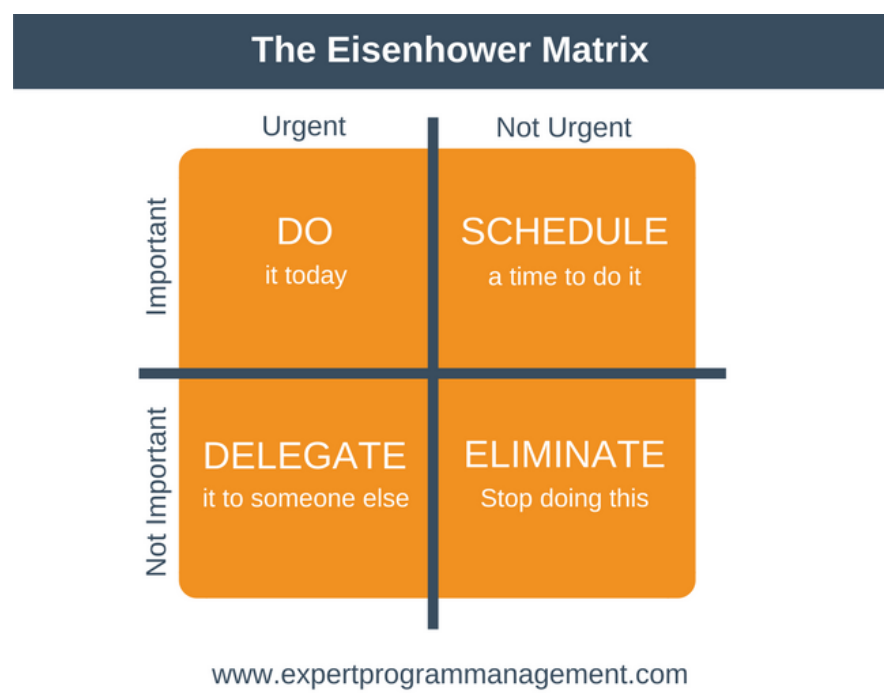

Kotak Eisenhower akan membantu Anda saat menetapkan prioritas. Dalam praktiknya, Anda ingin terlebih dahulu fokus pada tugas Penting dan Mendesak. Tugas yang Penting tetapi tidak Mendesak harus dijadwalkan ke kalender Anda. Tugas yang mendesak tetapi tidak penting harus didelegasikan jika memungkinkan. Dan tugas yang Tidak Penting atau Mendesak harus dihilangkan dari daftar tugas Anda sepenuhnya. Dengan memprioritaskan tugas dengan cara ini, Anda akan membiarkan diri Anda benar-benar fokus pada hal-hal penting tanpa terganggu.

\section{Manfaatkan Aturan 80/20}

Cara lain untuk memprioritaskan tugas adalah dengan menggunakan aturan 80/20. Dikembangkan oleh ekonom Italia Vilfredo Pareto, aturan ini menyatakan bahwa 20\% dari pekerjaan Anda akan menghasilkan $80 \%$ dari hasil Anda. Ini adalah konsep yang sangat penting ketika dipahami dan diterapkan! 
Hasil akhirnya tidak selalu sama dengan pemisahan sempurna 80/20, tetapi jika Anda melihat-lihat, Anda akan menemukan prinsip ini benar dalam banyak skenario yang berbeda. Contoh

20\% tanaman di kebun Anda menghasilkan $80 \%$ dari hasil.

20\% salesman di perusahaan Anda menghasilkan $80 \%$ dari penjualan.

20\% pelanggan organisasi Anda menghasilkan 80\% dari pendapatannya.

$20 \%$ dari pakaian di lemari Anda dikenakan $80 \%$ dari waktu.

Untuk menggunakan aturan 80/20 saat menetapkan prioritas, analisis item pada daftar tugas Anda. Manakah dari mereka yang akan memiliki dampak terbesar pada proyek, karier, dan kehidupan Anda saat ini? Ini adalah tugas-tugas yang harus Anda fokuskan. Segala sesuatu yang lain dapat didelegasikan, dijatuhkan, atau diselesaikan setelah Anda menyelesaikan tugas yang paling penting.

\section{Makan Katak Dulu}

Bisakah Anda membayangkan sesuatu yang lebih buruk daripada memakan katak raksasa yang menggeliat dan berkutil? Mungkin Anda bisa, tetapi memakan amfibi hidup pasti harus menjadi yang teratas dalam daftar "hal-hal yang harus dihindari"! Dan itulah mengapa Anda harus makan katak Anda terlebih dahulu di pagi hari.

Ketika kami mengatakan "katak" yang kami maksud adalah proyek besar yang tidak menyenangkan yang telah Anda tunda-tunda. Yang membuat Anda takut dan kewalahan atau tampaknya sangat membosankan. Saat menetapkan prioritas, mungkin akan membantu jika Anda menyisihkan waktu untuk tugas terberat Anda di pagi hari. Dengan begitu mereka benar-benar selesai dan Anda tidak bisa terus mendorongnya.

Jika Anda bertanya-tanya, pepatah "makan katak dulu" telah dikaitkan dengan penulis terkenal Amerika Mark Twain, meskipun tidak ada bukti substansial bahwa dia yang mengemukakannya atau bahkan mengatakannya. Kutipan yang dikaitkan adalah, 
"Makan Katak Hidup Setiap Pagi, dan Tidak Ada Hal Lebih Buruk yang Akan Terjadi Pada Anda Sepanjang Hari."

Terlepas dari dari mana pepatah ini berasal, itu adalah konsep yang berharga. Jika Anda bergumul dengan penundaan, sebaiknya Anda menjadwalkan tugas tersulit Anda terlebih dahulu di pagi hari.

\section{Gunakan Metode ABCDE}

Akhirnya, Metode ABCDE Brian Tracy adalah kerangka kerja yang sederhana dan efisien untuk menetapkan prioritas. Pertama, duduk dengan pena dan kertas dan tuliskan setiap tugas yang perlu Anda selesaikan. Kemudian lanjutkan dan tandai setiap tugas dengan huruf mulai dari A hingga $E$.

Tugas "A" sangat penting. Jika tidak dilakukan, Anda dan/atau bisnis Anda akan mengalami konsekuensi serius. "B" adalah singkatan dari tugas-tugas penting. Itu adalah hal-hal yang harus Anda lakukan, tetapi hanya akan menghasilkan konsekuensi kecil jika dibiarkan. Tugas "C" adalah tugas yang ingin Anda selesaikan tetapi tidak mewakili konsekuensi negatif apa pun jika tidak diselesaikan. "D" adalah singkatan dari delegasi. Ini adalah tugas yang harus diselesaikan, bukan oleh Anda. Kirim mereka ke orang lain. Tugas "E" harus dihilangkan. Semakin banyak pekerjaan yang Anda coret dari daftar tugas dengan segera, semakin banyak waktu yang Anda miliki untuk tugas yang paling penting.

Menurut Brian, "walaupun tidak pernah ada cukup waktu untuk melakukan semuanya, selalu ada cukup waktu untuk melakukan hal-hal yang paling penting, dan tetap bersama mereka sampai selesai." Metode ABCDE akan membantu Anda menemukan hal-hal penting dan menyelesaikannya (Rabiudin \& Nurafifi, 2021).

\section{Kesimpulan}


Jika Anda ingin mencapai tujuan Anda (dan siapa yang tidak), menetapkan prioritas dengan benar sangat penting. Taktik dan sistem dalam posting blog ini akan membantu Anda. Ingat, menetapkan prioritas dimulai dengan perubahan pola pikir. Anda perlu mengambil pandangan jangka panjang tentang kehidupan dan karier Anda. Melakukannya akan membantu Anda mengidentifikasi S.M.A.R.T. tujuan dan urutkan daftar tugas Anda secara efektif. Untuk lebih memahami tugas Anda yang mana yang harus diberi prioritas tertinggi, bereksperimenlah dengan kerangka kerja berbeda yang kami uraikan: Kotak Eisenhower, Aturan 80/20, Makan Katak Dulu, dan Metode ABCDE. Selamat memprioritaskan.

\section{Referensi}

Rabiudin, \& Nurafifi, E. H. (2021). Development of USA method (understanding, sketching, analysing) as practical way to resolving classical mechanics problems for physics lesson. Journal of Physics: Conference Series, 1957(1), 0-11. https://doi.org/10.1088/1742-6596/1957/1/012043

Rabiudin, Taruh, E., \& Mursalin. (2018). Development of Authentic Affective Assessment Instrument in High School Physics Learning. Journal of Physics: Conference Series, 1028(1). https://doi.org/10.1088/1742-6596/1028/1/012201

Tracy, B. (2014). Time Management (The Brian Tracy Success Library). Amacom. 